\section{Guilty But Mentally III}

Nathalie DeFabrique

Cook County Department of Corrections, Chicago, IL, USA

\section{Synonyms}

Legal insanity

\section{Definition}

Guilty but mentally ill is a verdict available in some jurisdictions in cases involving an insanity defense in which the defendant is considered guilty but is committed to a mental hospital rather than imprisoned. This plea is utilized if an examination shows a need for psychiatric treatment, and the metal illness interfered with the person's ability to determine right from wrong.

In general, a person who pleads guilty but mentally ill may do so if the trier of fact finds that during the time of the incident, the person was mentally ill at the time of the offense beyond a reasonable doubt. In order to proceed with the plea, the person who chooses guilty but mentally ill waives the right to trial if it is accepted by the judge. The judge will consider the rules of criminal procedure and hold a hearing for the sole purpose of determining whether sufficient evidence can be presented indicating that the defendant was mentally ill at the time of the offense. If the judge refuses to accept the plea of guilty but mentally ill, the defendant may withdraw the plea and is then entitled to a jury trial. If the defendant waives the right to a jury trial, the judge who presided at the hearing on mental illness may not preside at the subsequent trial.

To be considered mentally ill by the courts, the individual lacks significant capacity to either appreciate the wrongfulness of his actions or to obey the rules of conduct to the requirements of the law as a result of the mental disease or defect.

\section{Cross-References}

Insanity

\section{References and Readings}

Brown, M. (2007). The John Hinckley trial \& its effect on the insanity defense.

Dalby, J. T. (2006). The case of Daniel McNaughton: Let's get the story straight. American Journal of Forensic Psychiatry, 27, 17-32.

Ellis, J. W. (1986). The consequences of the insanity defense: Proposals to reform post-acquittal commitment laws. Catholic University Law Review, 35, 961.

Schmalleger, F. (2001). Criminal justice: A brief introduction. Saddle River: Prentice Hall. ISBN 013396731X.

Walker, N. (1985). The insanity defense before 1800. The Annals of the American Academy of Political and Social Science, 477, 25. doi:10.1177/ 0002716285477001003. at p. 30. 